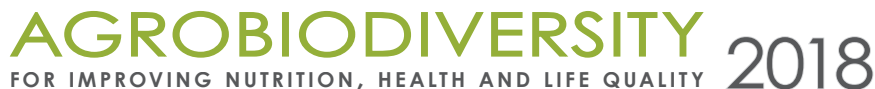

e

\section{ANTIOXIDANT AND ANTIMICROBIAL ACTIVITY OF BUNIAS ORIENTALIS L. AND SCORZONERA HISPANICA L. ETHANOL EXTRACTS}

\author{
Vergun Olena $^{1 *}$, Kačaniova Miroslava ${ }^{2}$, Rakhmetov Dzhamal ${ }^{1}$, \\ Shymanska Oksana ${ }^{1}$, Bondarchuk Oleksandr ${ }^{1}$, Brindza Jan ${ }^{2}$, Ivanišova Eva ${ }^{2}$

\footnotetext{
${ }^{1}$ M.M. Gryshko National Botanical Garden of NAS of Ukraine, Department of Cultural Flora, Kyiv, Ukraine

${ }^{2}$ Slovak University of Agriculture in Nitra, Institute of Biodiversity Conservation and Biosafety, Nitra, Slovakia
}

Received: 12.11.2018 Revised: 15. 11.2018 Published: 10. 12. 2018

The current study was aimed to evaluate an accumulation in plant raw material of Bunias orientalis L. and Scorzonera hispanica L. the total content of phenolic compounds, phenolic acids, flavonoids, antioxidant activity (by DPPH-method) and reducing power of alcoholic extracts. Raw of investigated plants collected from experimental collections of M.M. Gryshko National Botanical Garden of the NAS of Ukraine (Kyiv) and dried for next investigation. Obtained results showed that total content of polyphenols in the above-ground parts of B. orientalis extracts was $52.88 \mathrm{mg} \mathrm{g}^{-1}$ GAE (gallic acid equivalent), phenolic acids - $11.29 \mathrm{mg} \mathrm{g}^{-1} \mathrm{CAE}$ (caffeic acid equivalent), flavonoids - $39.91 \mathrm{mg} \mathrm{g}^{-1} \mathrm{QE}$ (quercetin equivalent), antioxidant activity $-8.94 \mathrm{mg} \mathrm{g}^{-1} \mathrm{TE}$ (Trolox equivalent) and reducing power of extracts $-184.59 \mathrm{mg} \mathrm{g}^{-1} \mathrm{TE}$ (Trolox equivalent). Total content of polyphenols in the above-ground parts of $S$. hispanica plants was $60.16 \mathrm{mg} \mathrm{g}^{-1} \mathrm{GAE}$, phenolic acids $-20.71 \mathrm{mg} \mathrm{g}^{-1} \mathrm{CAE}$, flavonoids $-36.24 \mathrm{mg}$ $\mathrm{g}^{-1} \mathrm{QE}$, antioxidant activity $-5.35 \mathrm{mg} \mathrm{g}^{-1} \mathrm{TE}$ and reducing power of extracts $-125.40 \mathrm{mg} \mathrm{g}^{-1} \mathrm{TE}$. Also, total content of polyphenols in the roots of $B$. orientalis extracts was $9.75 \mathrm{mg} \mathrm{g}^{-1} \mathrm{GAE}$, phenolic acids $1.73 \mathrm{mg} \mathrm{g}^{-1} \mathrm{CAE}$ and reducing power of extracts $-138.70 \mathrm{mg} \mathrm{g}^{-1} \mathrm{TE}$. Root extracts of $S$. hispanica had total content of polyphenols of $10.87 \mathrm{mg} \mathrm{g}^{-1} \mathrm{GAE}$, phenolic acids $-2.62 \mathrm{mg} \mathrm{g}^{-1} \mathrm{CAE}$ and reducing power of extracts $-110.96 \mathrm{mg} \mathrm{g}^{-1} \mathrm{TE}$. Flavonoids and antioxidant activity in the root extracts of both species weren't determined. The antimicrobial activity of alcoholic extracts of two investigated species was tested against 8 microorganisms by disc diffusion method. It was found that higher activity against microbial strains had alcoholic extracts of $B$. orientalis roots.

Keywords: Bunias orientalis, Scorzonera hispanica, antioxidant activity, polyphenols, flavonoids, phenolic acids, antimicrobial activity

*Corresponding author: Vergun Olena, M.M. Gryshko National Botanical Garden of NAS of Ukraine, Department of Cultural Flora, Kyiv, Timiryazevska 1, 01014 Kyiv, Ukraine; olenavergun8003@gmail.com 


\section{Introduction}

Plants are potential sources of natural antioxidants with therapeutic properties that can be used in traditional and folk medicine (Chandra et al., 2014; Ivanišova et al., 2017). Representatives of Asteraceae Bercht. \& J. Presl and Brassicaceae Burnett also are the good source of antioxidant compounds of different nature (Martinez-Sanchez et al., 2007; Vijaylakshmi et al., 2009; Sikora and Bodziarczyk, 2012). Cruciferous vegetables act as a good source of natural antioxidants due to the high levels of carotenoids, tocopherols and ascorbic acid (Ateya et al., 2016). Bunias orientalis L. (Turkish cabbage) is biennial or perennial hemicryptophyte that belongs to Brassicaceae. A recent study of $B$. orientalis connected with a high possibility to root because of powerful taproot leading to massive sprawl (Oliver et al., 2015). The complex of characteristics (biochemical toxicity, allelopathic effect, powerful taproot etc.) explained this plant as invasive (Dietz and Winterhalter, 1996; Dietz et al., 1999; Patamsitè et al., 2013). Also, it was studied nectar production and carbohydrate composition of this species (Denisow et al., 2016). Nevertheless, the accumulation of some biochemical compounds in different organs causes the useful properties of B. orientalis (Vinogradova and Kuklina, 2018). In the M.M. Gryshko Botanical Garden of the NAS of Ukraine have been studying these plants as forage and energetic culture and has been conducted selection work. Raw of this species is rich on protein, lipids, ash, ascorbic acid, carotene etc. (Uteush and Lobas, 1996).

Another species from Asteraceae family belongs to the genus of Scorzonera L. Some species of this genus have been used as traditional medicines with analgesic, antirheumatic, anthelmintic, stomachic and diuretic effects. These plants can be used for the treatment of the wound, hypertension, infertility, lung oedema, diarrhoea etc. (Sari et al., 2009). As reported Acikara Bahadir et al. (2013a), the plants of Scorzonera species used as medicinal and vegetable cultures possess promising antioxidant activity. One of the most effective compounds from antioxidants was found a chlorogenic acid. Extracts from some species of Scorzonera showed the activity on the wound healing that can be connected with the combined effect of the constituents (Küpeli et al., 2011). Useful properties of Scorzonera species for the food industry because of valuable biochemistry content were described (Mahjoub et al., 2009; Çitoğlu et al., 2010; Bashta et al., 2015). Some studies reported that raw of these plants contains flavonoids (apigenin, luteolin, kaempferol, rutin etc.) and triterpenoids (lupeol, daucosterol etc.) (Küpeli et al., 2011; Acikara et al., 2013; Benabdelaziz et al., 2014). Çetin et al. (2018) reported about seventeen triterpenoids in S. veratrifolia. However, the information about Scorzonera species is considerably limited in the existing literature (Erden and Kirbağ, 2015).

The aim of this study was to assess an antioxidant and an antimicrobial potential of Bunias orientalis L. and Scorzonera hispanica L. in the conditions of M.M. Gryshko National Botanical Garden of the NAS of Ukraine.

\section{Material and methodology}

The plants were grown in 2017 at the experimental fields of the M.M. Gryshko National Botanical Garden of the NAS of Ukraine (NBG) in the Kiev city (50 24' 55" N, 30 33' 45" E). 


\section{Biological material}

Observation on plants was conducted in the experimental collection of forage plants (Bunias orientalis L.) and vegetables crops (Scorzonera hispanica L.) of Cultural Flora Department of NBG. Plant raw material of investigated plants was collected in the stages of spring vegetation. In this study used above-ground part and roots of B. orientalis and above-ground part of S. hispanica.

\section{Biochemical analysis}

The biochemical analysis was done in the Slovak University of Agriculture in Nitra (Slovak Republic). For planned analyses, $0.2 \mathrm{~g}$ of milling fraction was extracted with $20 \mathrm{ml}$ of $80 \%$ ethanol for 24 hours. After centrifugation at $4000 \mathrm{~g}$ with Rotofix $32 \mathrm{~A}$ (Hettich, Germany) for $20 \mathrm{~min}$, the supernatant was used for measurement of the total content of polyphenols.

\section{Radical scavenging assay}

The radical scavenging activity of samples was measured using 2.2-diphenyl-1-picrylhydrazyl (DPPH) (Sanchez-Moreno et al., 1998). The extracts $(0.5 \mathrm{~mL})$ were mixed with $3.6 \mathrm{~mL}$ of radical solution ( $0.025 \mathrm{~g}$ of DPPH in $100 \mathrm{~mL}$ ethanol). The absorbance of the sample extract was determined using the spectrophotometer Jenway (6405 UV/Vis, England) at $515 \mathrm{~nm}$. Trolox (6-hydroxy-2,5,7,8-tetramethylchroman-2-carboxylic acid) (10-100 mg. $\mathrm{L}^{-1} ; R^{2}=0.988$ ) was used as the standard and the results were expressed in $\mathrm{mg} \mathrm{g}^{-1}$ Trolox equivalents.

\section{Reducing power}

Reducing power of extracts was determined by the phosphomolybdenum method of Prieto et al. (1999) with slight modifications. The mixture of sample $(1 \mathrm{~mL})$, monopotassium phosphate $(2.8 \mathrm{~mL}, 0.1 \mathrm{M})$, sulfuric acid $(6 \mathrm{~mL}, 1 \mathrm{M})$, ammonium heptamolybdate $(0.4 \mathrm{~mL}, 0.1 \mathrm{M})$ and distilled water $(0.8 \mathrm{~mL})$ incubated at $90{ }^{\circ} \mathrm{C}$ for $120 \mathrm{~min}$, then rapidly cooled and detected by monitoring absorbance at $700 \mathrm{~nm}$ using the spectrophotometer Jenway (6405 UV/Vis, England). Trolox $\left(10-1000 \mathrm{mg} . \mathrm{L}^{-1} ; R^{2}=0.998\right)$ was used as the standard and the results were expressed in $\mathrm{mg} \mathrm{g}^{-1}$ Trolox equivalents.

\section{Total polyphenol content}

Total polyphenol content extracts was measured by the method of Singleton and Rossi (1965) using Folin-Chiocalteu reagent. $0.1 \mathrm{~mL}$ of each sample extract was mixed with $0.1 \mathrm{~mL}$ of the Folin-Chiocalteu reagent, $1 \mathrm{~mL}$ of $20 \%(\mathrm{w} / \mathrm{v})$ sodium carbonate and 8.8 $\mathrm{mL}$ of distilled water. After $30 \mathrm{~min}$. in darkness the absorbance at $700 \mathrm{~nm}$ was measured using the spectrophotometer Jenway (6405 UV/Vis, England). Gallic acid (25-250 mg.L ${ }^{-1}$; $\left.R^{2}=0.996\right)$ was used as the standard and the results were expressed in $\mathrm{mg} \mathrm{g}^{-1}$ gallic acid equivalents.

\section{Total flavonoid content}

Determination of total flavonoids content was conducted according to procedure which was described by Shafii et al. (2017). $0.5 \mathrm{~mL}$ of sample extract was mixed with $0.1 \mathrm{~mL}$ of $10 \%$ $(\mathrm{w} / \mathrm{v}$ ) ethanolic solution of aluminium chloride, $0.1 \mathrm{~mL}$ of $1 \mathrm{M}$ sodium acetate and $4.3 \mathrm{~mL}$ of 
distilled water. After $30 \mathrm{~min}$. in darkness the absorbance at $415 \mathrm{~nm}$ was measured using the spectrophotometer Jenway (6405 UV/Vis, England). Quercetin (0.01-0.5 mg.L ${ }^{-1} ; R^{2}=0.997$ ) was used as the standard and the results were expressed in $\mu \mathrm{g} \mathrm{g}^{-1}$ quercetin equivalents.

\section{Total phenolic acid content}

Determination total phenolic acids content of extracts was carried out using method of Farmakopea Polska (1999). $0.5 \mathrm{~mL}$ of sample extract was mixed with $0.5 \mathrm{~mL}$ of $0.5 \mathrm{M}$ hydrochloric acid, $0.5 \mathrm{~mL}$ Arnova reagent, $0.5 \mathrm{~mL}$ of $1 \mathrm{M}$ sodium hydroxide (w/v) and $0.5 \mathrm{~mL}$ of distilled water. Absorbance at $490 \mathrm{~nm}$ was measured using the spectrophotometer Jenway (6405 UV/Vis, England). Caffeic acid (1-200 mg.L $\left.\mathrm{L}^{-1}, R^{2}=0.999\right)$ was used as a standard and the results were expressed in $\mathrm{mg} \mathrm{g}^{-1}$ caffeic acid equivalents.

\section{Preparation of plant extracts for determination of antimicrobial activity}

Plant raw material was dried, crushed and weighed out to $2 \mathrm{~g}$ and soaked in $20 \mathrm{~mL}$ of ethanol p.a. (Sigma, Germany) during two weeks at room temperature. After this ethanol plant extracts were filtered through the Whatman No. 1 filter paper. The obtained extracts were subjected to evaporation under reduced pressure at $40{ }^{\circ} \mathrm{C}$ in order to remove the ethanol (Stuart RE300DB rotary evaporator, Bibby Scientific Limited, UK, and vacuum pump KNFN838.1.2KT.45.18, KNF, Germany). For the antimicrobial assays, the crude plant extracts were dissolved in dimethylsulfoxide (Penta, Czech Republic) to $102.4 \mathrm{mg} \mathrm{mL}^{-1}$.

\section{Microbial strains}

Eight strains of microorganisms were tested in this study, including Bacillus cereus CCM 869, Candida albicans CCM 8215, Candida glabrata CCM 8270, Candida tropicalis CCM 8264, Clostridium perfingens CCM 4435T, Haemophilus influenza CCM 4456, Klebsiella pneumoniae subsp. pneumoniae CCM 4415, Salmonella enterica subsp. enterica CCM 7189. All tested strains collected from the Czech Collection of microorganisms. The bacterial suspensions were cultured in the nutrient broth at $37^{\circ} \mathrm{C}$.

\section{Disk diffusion method of determination of antibacterial activity}

Antibacterial activity of ethanol extracts of B. orientalis and S. hispanica were determined by a disc diffusion method. Briefly, $100 \mu \mathrm{L}$ of the test bacteria were grown in $10 \mathrm{~mL}$ of fresh media until they reached a count approximately $10^{5}$ cells. $\mathrm{mL}^{-1}$. Then $100 \mu \mathrm{L}$ of the microbial suspension was spread onto Mueller Hinton agar plates. The extracts were tested using $6 \mathrm{~mm}$ sterilized filter paper discs. The diameters of the inhibition zones were measured in millimetres. All antimicrobial assays were performed in at least triplicate. Negative control was a filter disc impregnated with $10 \mu \mathrm{L}$ of distilled water.

\section{Statistical analysis}

The statistically treated data are given in table as the arithmetical mean values and their standard errors. 


\section{Results and discussion}

Phenolic compounds are a large group of the secondary metabolites widespread in plants. These compounds possess different biological activities, but the most important is antioxidant activity (Soobrattee et al., 2005; Podsędek, 2007). Study of Mahboubi et al. (2013) expected that ethanolic or ethyl acetate extracts with higher level of total phenolic content would exhibit higher antioxidant activity. However, for example, Kähkönen et al. (1999) reported that antioxidant activity does not necessarily correlates with high amounts of phenolics.

Our previous data concerning Brassicaceae showed that total antioxidant activity of selected species was $16.94-36.91 \%$ in methanol extracts and $26.53-65.66 \%$ in water extracts (Vergun and Rakhmetov, 2018). As shown in Tables 1 and 2, total content of polyphenols, phenolic acids and flavonoids was higher in the above-ground part of plants of $B$. orientalis than in roots. The considering of obtained results in details showed that content of polyphenols in above-ground part was 5.4 times more than in roots, content of phenolic acids - 6.5 times respectively. Similar results obtained for $S$. hispanica extracts.

The most widespread and diverse group of the polyphenols are the flavonoids. They have been suggested to play a preventive role in the development of some disease. They are highly effective scavengers of most oxidizing molecules (Baba and Malik, 2015; Hudz et al., 2017). The total content of flavonoids and antioxidant activity by DPPH-method weren't determined in the roots of the investigated plants.

Table 1 The content of phenolic compounds and antioxidant activity in above-ground parts of Bunias orientalis L. and Scorzonera hispanica L. in the period of spring vegetation

\begin{tabular}{|c|c|c|}
\hline Parameter & Bunias orientalis & Scorzonera hispanica \\
\hline Total content of polyphenols ( $\mathrm{mg} \mathrm{g}^{-1} \mathrm{GAE}$ ) & $52.88 \pm 1.84$ & $60.16 \pm 1.01$ \\
\hline Total content of phenolic acids ( $\mathrm{mg} \mathrm{g}^{-1} \mathrm{CAE}$ ) & $11.29 \pm 1.00$ & $20.71 \pm 2.55$ \\
\hline Total content of flavonoids ( $\mathrm{mg} \mathrm{g}^{-1} \mathrm{QE}$ ) & $39.91 \pm 0.43$ & $36.24 \pm 2.14$ \\
\hline Antioxidant activity ( $\left.\mathrm{mg} \mathrm{g}^{-1} \mathrm{TE}\right)$ & $8.94 \pm 0.07$ & $5.35 \pm 0.12$ \\
\hline Reducing power of extract ( $\left.\mathrm{mg} \mathrm{g}^{-1} \mathrm{TE}\right)$ & $184.59 \pm 0.37$ & $125.40 \pm 1.00$ \\
\hline
\end{tabular}

Notes: Means in columns followed by different letters are different at $p=0.05$; each value represents the mean of three independent experiments $( \pm \mathrm{SD})$

As reported Acikara Bahadir et al. (2013b), the chlorogenic acid is one of the major constituent of Scorzonera species, which probably responsible for the biological activities of these plants. As described by Erden and Kirbağ (2015), the total phenolic content of soil surface parts of different species of Scorzonera was from 14.92 to $40.19 \mathrm{mg} \mathrm{g}^{-1}$ GAE and flavonoids - from 30.47 to $110.08 \mathrm{mg} \mathrm{g}^{-1} \mathrm{QE}$. Granica et al. (2015) revealed that both subaerial and aerial parts of $S$. hispanica contain caffeoylquinic acid derivatives, which are the major phenolics in this plant. Also, in this study showed that presence of flavonoids was confirmed in aerial part of S. hispanica. 
Vergun, O., Kačaniova, M., Rakhmetov, D., Shymanska, O., Bondarchuk, O., Brindza, J., Ivanišova, E. Agr.bio.div. Impr. Nut., Health Life Qual., 2018, 29-38

Table 2 The content of phenolic compounds and antioxidant activity in the roots of Bunias orientalis L. and Scorzonera hispanica L. in the period of spring vegetation

\begin{tabular}{|c|c|c|}
\hline Parameter & Bunias orientalis & Scorzonera hispanica \\
\hline Total content of polyphenols ( $\mathrm{mg} \mathrm{g}^{-1} \mathrm{GAE}$ ) & $9.75 \pm 0.54$ & $10.87 \pm 0.29$ \\
\hline Total content of phenolic acids ( $\left.\mathrm{mg} \mathrm{g}^{-1} \mathrm{CAE}\right)$ & $1.73 \pm 0.05$ & $2.62 \pm 0.26$ \\
\hline Total content of flavonoids ( $\left.\mathrm{mg} \mathrm{g}^{-1} \mathrm{QE}\right)$ & ND & ND \\
\hline Antioxidant activity (mg g-1 $\mathrm{TE})$ & ND & ND \\
\hline Reducing power of extract $\left(\mathrm{mg} \mathrm{g}^{-1} \mathrm{TE}\right)$ & $138.70 \pm 1.41$ & $110.96 \pm 6.88$ \\
\hline
\end{tabular}

Notes: Means in columns followed by different letters are different at $p=0.05$; each value represents the mean of three independent experiments $( \pm \mathrm{SD})$; ND - non determined.

The interest of natural plants products as antimicrobials is supported by the necessity to reduce the use of conventional antibiotics in food preservation (Ateya et al., 2016). Study of Prasad (2014) showed that different extracts of selected plants of Brassicaceae exhibited significant antimicrobial activity.

Investigation of the antimicrobial activity of root extracts of $B$. orientalis showed in the Figure 1. Our results of antibacterial testing with disc diffusion method demonstrate that Candida albicans and Salmonella enterica subsp. enterica were the most sensitive to B. orientalis root extract (5.00 and $4.33 \mathrm{~mm}$ respectively). Among tested bacteria, Bacillus cereus was the least sensitive $(1.00 \mathrm{~mm})$.

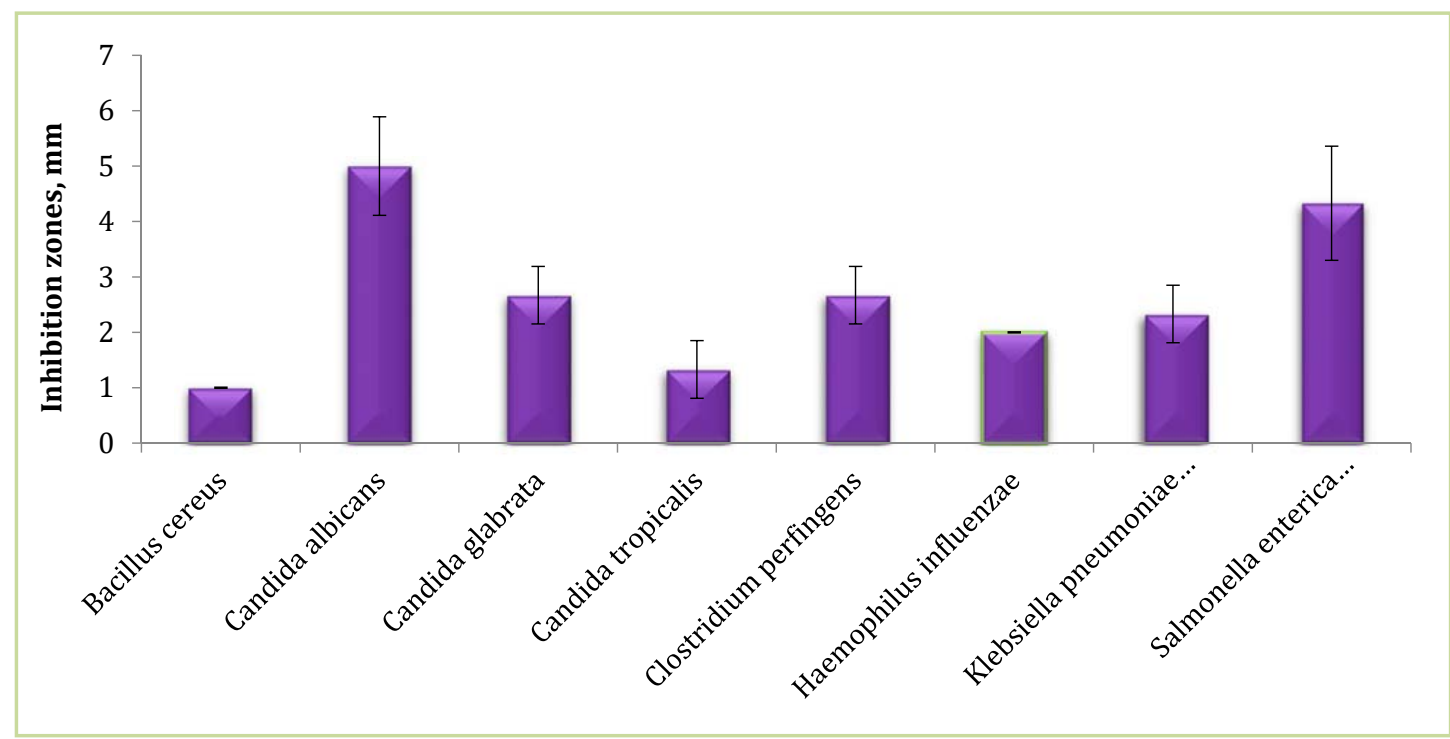

Figure 1 Antimicrobial activity of root plant extracts of Bunias orientalis L. (Means in columns followed by different letters are different at $p=0.05$; each value represents the mean of six independent experiments $( \pm \mathrm{SD})$ ) 
Our study showed also, that antimicrobial activity of above-ground extracts of $B$. orientalis wasn't determined. Ethanol root extracts weren't effective against all investigated microorganisms.

In the current research plant extracts (above-ground part) of S. hispanica showed antimicrobial activity against Salmonella enterica only. Inhibition zone in this case was $1.33 \pm 0.52 \mathrm{~mm}$. Root extracts weren't effective against all microorganisms. Results of Sari et al. (2009) showed that S. latifolia and S. veratrifolia ethanol extracts were able to inhibit the growth of Staphylococcus aureus, S. epidermidis, Shigella flexneri, Candida albicans. Better results were found for petroleum ether fraction. Another study of $S$. humilis L. reported that no antibacterial activity against Bacillus subtilis and nor antifungal activity against Candida albicans wasn't found (Zidorn et al., 2000; Zidorn et al., 2002). As reported Erden and Kirbağ (2015), three species of genus of Scorzonera showed antimicrobial effect on Escherichia coli (17-27 mm of inhibition zone) and none of the plant extracts showed any effect against Klebsiella pneumoniae. Two species showed the antimicrobial activity against Staphylococcus aureus (8 $\mathrm{mm}$ of inhibition zone).

\section{Conclusions}

Thus, results of current study showed that ethanol extracts of B. orientalis and S. hispanica demonstrated a higher antioxidant activity of the above-ground parts of plants then of roots (content of polyphenols and phenolic acids). The content of flavonoids was observed in the above-ground parts of plants; however, in roots it wasn't determined. Reducing power was higher in the extracts of above-ground parts. Alcoholic extracts from the roots of B. orientalis demonstrated antimicrobial effect against all tested microorganisms. The highest antimicrobial activity was found against Candida albicans and Salmonella enterica subsp. enterica. Root extracts of S. hispanica weren't effective against all tested microbial strains but extracts of above-ground part was non-significant effective against Salmonella enterica. Authors considered that alcoholic extracts of investigated plants could be beneficial for new microbiological and pharmacological study.

\section{Acknowledgements}

The publication was prepared with the active participation of researchers involved in the International network AgroBioNet of the Institutions and researchers for realization of research, education and development program «Agrobiodiversity for improving nutrition, health and life quality» and authors are grateful to SAIA, n.o. Programmes for supporting.

\section{References}

ACIKARA BAHADIR, Ö., ÇİTOĞLU SALTAN, G., ÇOBAN, T. 2013a. Phytochemical screening and antioxidant activities of selected Scorzonera species. In Turkish Journal of Pharmaceutical Sciences, vol. 10(3), p. 453-462.

ACIKARA BAHADIR, Ö., ÇiTOĞLU SALTAN, G., ÖZKAN GENÇLER, M.A. 2013b. Qualitative and quantitative analysis of phenolic acids in Scorzonera tomentoza L. In Turkish Journal of Pharmaceutical Sciences, vol. 10(1), p. 1-8. 
ATEYA, A., AL-GENDY, A., KOTOB, S., HAFEZ, A. 2016. Chemical constituents, antioxidant, antimicrobial and anti-inflammatory activities of Erysimum corinthium Boiss. (Brassicaceae). In International Journal of Pharmagnosy and Phytochemical Research, vol. 8(10), p. 1601-1609.

BABA, A.S., MALIK, A.SH. 2015. Determination of total phenolic and flavonoid content, antimicrobial and antioxidant activity of a root extract of Arisaema jacjuemontii Blume. In Journal of Taibah University for Science, vol. 9(4), p. 449-454. https://doi.org/10.1016/j.jtusci.2014.11.001

BASHTA, A., IVCHUK, N., BASHTA, O. 2015. Yakon and Scorzonera as functional enrichment of food. In Ukrainian Journal of Food Sciences, vol. 3(1), p. 13-22.

BENABDELAZIZ, I., HABA, H., LAVAUD, C., BENKHALED, M. 2014. Triterpenoids and Flavonoid from Scorzonera undulata ssp. Alexandrina. In International Journal of Chemical and Biochemical Sciences, vol. 5, p. 1-5.

ÇETIN, B., ŞAHIN, H., SARI, A. 2018. Triterpenoids from Scorzonera veratrifolia Fenzl. In Istanbul Journal of Pharmacology, vol. 48(2), p. 23-27. http://dx.doi.org/10.5152/IstanbulJPharm.2018.410411

ÇİTOĞLU SALTAN, G., BAHADIR, Ö., DALL'ACQUA, S. 2010. Dihydroisocoumarin derivatives isolated from the roots of Scorzonera latifolia. In Turkish Journal of Pharmacological Sciences, vol. 7(3), p. 205-212.

CHANDRA, S., KHAN, S., AVULA, B., LATA, H., YANG, H.M., ELSOHLY, A.M., KHAN, A.I. 2014. Assessment of total phenolic and flavonoid content, antioxidant properties, and yield of aeroponically and conventionally grown leafy vegetables and fruit crops: a comparative study. In Evidence-Based Complementary and Alternative Medicine, article ID 253875. http://dx.doi. org/10.1155/2014/253875

DENISOW, B., MASIEROWSKA, M., ANTON, S. 2016. Floral nectar production and carbohydrate composition and the structure of receptacular nectaries in the invasive plant Bunias orientalis L. (Brassicaceae). In Protoplasma, vol. 253, p. 1489-1501. http://dx.doi.org/10.1007/ s00709-015-0902-6

DIETZ, H., STEINLEIN, T., ULLMANN, I. 1999. Establishment of the invasive perennial herb Bunias orientalis L. : an experimental approach. In Acta Oecologica, vol. 20, p. 621-632.

DIETZ, H., WINTERHALTER, P. 1996. Phytotoxic constituents from Bunias orientalis L. In Phytochemistry, vol. 42(4), p. 1005-1010.

ERDEN, Y., KIRBAĞ, S. 2015. Chemical and biological activities of some Scorzonera species: an in vitro study. In Proceedings of the National Academy of Sciences, India - Section B : Biological Sciences, vol. 85(1), p. 319-326. http://dx.doi.org/10.1007/s40011-013-0240-4

FARMAKOPEA POLSKA. 1999. The Polish Farmaceutical Society. http://www.ptfarm.pl/?pid= 1\&language $=$ en

HUDZ, N., NIKOLAEVA, N., KONYK, CH., KAPLUN, I., ŠIMKOVA, J., GRYGORIEVA, O. 2017. Sposoby vyznachennya sumarnoho vmistu flavonojidiv v roslynnyh produktah spektrofotometrychnym metodom [Methods of determination of sum of flavonoids in herbal products by spectrophotometric methods]. In Agrobiodiversity for improving nutrition, health and life quality, vol. 1, p. 174-178. http://dx.doi.org/10.15414/agrobiodiversity.2017.2585-8246.174-177

IVANIŠOVA, E., KRAJČOVIČ, T., TOKÁR, M., DRAB, Š., KANTOR, A., KAČÁNIOVÁ, M. 2017. Potential of wild plants as a source of bioactive compounds. In Scientific Papers: Animal Science and Biotechnologies, vol. 50(1), p. 109-114. http://dx.doi.org/10.16/j.lwt.2005.07.023

GRANICA, S., LOHWASSER, U., JOHRER, K., ZIDORN, C. 2015. Qualitative and quantitative analyses of secondary metabolites in aerial and subaerial of Scorzonera hispanica L. (black salsify). In Food Chemistry, vol. 173, p. 321-331. http://dx.doi.org/10.1016/j.foodchem.2014.10.006 
KÄHKÖNEN, P.M., HOPIA, I.A., VUORELA, J.H., RAUHA, J.-P., PIHLAJA, K., KUJALA, S.T., HEINONEN, M. 1999. Antioxidant activity of plant extracts containing phenolic compounds. In Journal of Agricultural Food Chemistry, vol. 47, p. 3954-3962. http://dx.doi.org/10.1021/jf9901461

KÜPELI A.E., ACIKARA Ö.B., SUNTARA, I., ÇiTOĞLU SALTAN, G., KELEŞ, H., ERGENE, B. 2011. Enhancement of wound healing by topical application of Scorzonera species: determination of the constituents by HPLC with new validated reverse phase method. In Journal of Ethnopharmacology, vol. 137, p. 1018-1027. http://dx.doi.org/10.1016/j.jep.2011.07.029

MAHBOUBI, M., KAZEMPOUR, N., NAZAR BOLAND, R.A. 2013. Total phenolic, total flavonoids, antioxidant and antimicrobial activities of Scrophularia striata Boiss extracts. In Pharmaceutical Products, vol. 8(1), p. 15-19.

MAHJOUB, M.A., BOUSSAADA, O., AMMAR, S., SAIDANA, D., CHRAIF, I., HELAL, A.N., MIGHRI, Z. 2009. Chemical composition and antioxidant activity of the volatile components obtained from the subaerial parts of Scorzonera indulate. In International Journal of Essential Oil Therapeutics, vol. 3, p. $152-157$.

MARTINEZ-SANCHES, A., LLORACH, R., GIL, M.I., FERRERES, F. 2007. Identification of new flavonoid glycosides and flavonoid profiles to characterize rocket leafy salads (Eruca vesicaria and Diplotaxis tenuifolia). In Journal of Agriculture and Food Chemistry, vol. 55, p. 1356-1363.

OLIVER, W.B., BRANDSÆTER, O.L., GOVASHMARK, E., FLØISTAD SUNDHEIM, I. 2015. Sprouting dynamics of Bunias orientalis. In Journal of Plant Diseases and Protection, vol. 3, p. 141-149.

PATAMSITĖ, J., ČĖSNIENĖ, T., NAUGŽEMYS, D., KLEIZAITĖ, V., TUNAITIENĖ, V., VAITKŪNIENĖ, V., RANČELIS, V., MIKALIŪNAITĖ, R., ŽVINGILA, D. 2013. Different habitats show similar genetic structure of Bunias orientalis L. (Brassicaceae) in Lithuania. In Notulae Botanicae Horti Agrobotanici, vol. 41(2), p. 396-403. http://dx.doi.org/10.15835/nbha4129186

PODSĘDEK, A. 2007. Natural antioxidants and antioxidant capacity of Brassica vegetables: a review. In LWT, vol. 40, p. 1-11.

PRASAD, M.P. 2014. Antimicrobial potential of Brassicaceae family against clinical isolates. In International Journal Pure and Applied Bioscience, vol. 2(2), p. 158-162.

PRIETO, P., PINEDA, M., AGUILAR, M. 1999. Spectrophotometric quantitation of antioxidant capacity through the formation of a phosphomolybdemun complex: specific application to the determination of vitamin E. In Analytical Biochemistry, vol. 269, p. 337-341.

SÁNCHÉZ-MORENO, C., LARRAURI, A., SAURA-CALIXTO, F. 1998. A procedure to measure the antioxidant efficiency of polyphenols. In Journal of the Science of Food and Agriculture, vol. 76(2), p. 270-276.

SARI, A., ÖZBEK, B., ÖZGOKÇE, F. 2009. Antimicrobial activities of two Scorzonera species growing in Turkey. In Asian Journal of Chemistry, vol. 21(6), p. 4785-4788.

SHAFII, Z.A., BARSI, M., MALEK, E.A., ISMAIL, M. 2017. Phytochemical and antioxidant properties of Manilkara zapota (L.) P roen fruit extracts and its formulations for cosmeceutical application. In Asian Journal of Plant Science and Research, vol. 7 (3), p. 29-41.

SIKORA, E., BODZIARCZYK, I. 2012. Composition and antioxidant activity of kale (Brassica oleracea L. var. acephala) raw and cooked. In Acta Scientarium Polonorum, Technologia Alimentaria, vol. 11(3), p. 239-248.

SINGLETON, V.L., ROSSI, J.A. 1965.Colorimetry of total phenolics with phosphomolybdic-phosphotungstic acid reagent. In American Journal of Enology and Agricultural, vol. 6, p. 144-158.

SOOBRATTEE, M., NEERGHEEN, V.S., LUXIMON-RAMMA, A., ARUOMA, O.I., BAHORUM, T. 2005. Phenolics as potential antioxidant therapeutic agents: mechanism and actions. In Mutation Research, vol. 579, p. 200-213.

UTEUSH, YU.A., LOBAS, M.H. 1996. Kormovi resursy flory Ukrajiny [The forage resources of Ukrainian flora]. Kyiv : Naukova dumka, 222 p. ISBN 5-12-004685-1. (In Ukrainian). 
VERGUN, O.M., RAKHMETOV, D.B. 2018. Antioxidant potential of some plants of Brassicaceae Burnett and Poaceae Barnthart. In Introdukciia Roslyn, vol. 77 (1), p. 87-95.

VIJAYLAKSHMI, S., NANJAN, M.J., SURESH, B. 2009. In vitro antioxidant activities of Asteraceae plants. In Ancient Science of Life, vol. 29(2), p. 3-6.

VINOGRADOVA, YU., KUKLINA, A. 2018. Useful properties of invasive plants. Slovak University of Agriculture in Nitra, 105 p. https://doi.org/10.15414/2018.fe-9788055218571

ZIDORN, C., ELLMERER-MÜLLER, E.P., STUPPNER, H. 2000. Tyrolobibenzyls-novel secondary metabolites from Scorzonera humilis L. In Helvetica Chimica Acta, vol. 83, p. 2920-2925.

ZIDORN, C., SPITALER, R., ELLMERER- MÜLLER, E.P., PERRY, N.B., GERHAUSER, C., STUPPNER, H. 2002. Structure of tyrolobibenzyl D and biological activity of tyrolobibenzyls from Scorzonera humilis L. In Zeitschrift Naturforschung B, vol. 57(7-8), p. 614-619. 